\title{
Concentrates based on sorghum grain provide a basis for a finishing system for crossbred lambs
}

\author{
M. K. Bowen $\mathrm{A}, \mathrm{C}, \mathrm{D}$, P. M. Pepper ${ }^{\mathrm{B}}$, J. Winkleman ${ }^{\mathrm{A}}$ and I. McConnel/ \\ ADepartment of Primary Industries and Fisheries, PO Box 519, Longreach, Qld 4730, Australia. \\ BDepartment of Primary Industries and Fisheries, Locked Mail Bag 4, Moorooka, Qld 4105, Australia. \\ CPresent address: Department of Primary Industries and Fisheries, PO Box 6014, Rockhampton, QId 4702, Australia. \\ DCorresponding author. Email: maree.bowen@dpi.qld.gov.au
}

\begin{abstract}
In parts of Australia, sorghum grain is a cheaper alternative to other cereal grains but its use and nutritive value in sheep feeding systems is not well understood. The aim of this work was to compare growth and carcass characteristics for crossbred lambs consuming several simple, sorghum-based diets. The treatments were: (1) whole sorghum grain, (2) whole sorghum grain + urea and ammonium sulfate, (3) cracked sorghum grain + urea and ammonium sulfate, (4) expanded sorghum grain + urea and ammonium sulfate, (5) whole sorghum grain + cottonseed meal, and (6) whole sorghum grain + whole cottonseed. Nine lambs were slaughtered initially to provide baseline carcass data and the remaining 339 lambs were gradually introduced to the concentrate diets over 14 days before being fed concentrates and wheaten hay ad libitum for 41, 56 or 76 days.

Neither cracking nor expanding whole sorghum grain with added non-protein nitrogen $(\mathrm{N})$ resulted in significantly $(P>0.05)$ increased final liveweight, growth rates or carcass weights for lambs, or in decreased days on feed to reach $18-\mathrm{kg}$ carcass weight, although carcass fat depth was significantly $(P<0.05)$ increased compared with the whole sorghum plus non-protein $\mathrm{N}$ diet. However, expanding sorghum grain significantly $(P<0.05)$ reduced faecal starch concentrations compared with whole or cracked sorghum diets with added non-protein N (79v. $189 \mathrm{~g} / \mathrm{kg}$ DM after 59 days on feed). Lambs fed whole sorghum grain without an additional $\mathrm{N}$ source had significantly $(P<0.05)$ lower concentrate intake and required significantly $(P<0.05)$ more days on feed to reach a carcass weight of $18 \mathrm{~kg}$ than for all diets containing added N. These lambs also had significantly $(P<0.05)$ lower carcass weight and fat depth than for lambs consuming whole sorghum plus true protein diets. Substituting sources of true protein (cottonseed meal and whole cottonseed) for nonprotein N (urea and ammonium sulfate) did not significantly $(P>0.05)$ affect concentrate intakes or carcass weights of lambs although carcass fat depth was significantly $(P<0.05)$ increased and the days to reach 18 -kg carcass weight were significantly $(P<0.05)$ decreased for the whole sorghum plus cottonseed meal diet.

In conclusion, processing sorghum grain by cracking or expanding did not significantly improve lamb performance. While providing an additional $\mathrm{N}$ source with sorghum grain significantly increased lamb performance, there was no benefit in final carcass weight of lambs from substituting sources of true protein for non-protein $\mathrm{N}$.
\end{abstract}

\section{Introduction}

Australia currently produces 17.4 million lambs annually, exporting 30\% (117500 tonnes) of production (Meat and Livestock Australia 2005). Strong market demand for lamb, as well as the requirement for consistent quality and year-round availability of product, has increased the need for grainfinishing systems and improvement in their management.

In parts of Australia, sorghum grain is a cheaper alternative to other cereal grains but its use and nutritive value in sheep feeding systems is not well understood (Beretta and Kirby 2004). In addition to sorghum, protein supplements based on cottonseed are normally readily available in tropical and subtropical areas but have not been extensively used in sheep feeding systems despite their attractive nutritional composition and price.

In cattle, it has been widely documented that sorghum has a lower digestibility of starch compared with winter cereal grains, due largely to the encasement of starch granules in a protective protein matrix inside the hard peripheral endosperm layer of the grain (Rooney and Pflugfelder 1986). This can also affect the degradability of the protein fraction in sorghum, with McLennan (1997) showing a lower digestibility of nitrogen (N) in sorghum compared with barley diets in experiments with beef cattle. In vitro fermentation and digestion studies have produced results consistent with the in vivo observations of a lower feeding value of sorghum for cattle (e.g. Bird et al. 1999).

While few studies are available for sorghum grain fed to sheep, a previous experiment (Bowen et al. 2007) showed high levels of faecal starch [240-310 g/kg dry matter (DM)] for sheep consuming whole sorghum diets. These results are similar to those for cattle consuming cracked sorghum diets $(252 \mathrm{~g} / \mathrm{kg}$ DM; McLennan 1997) and indicate that sorghum starch may have a similar low digestibility for sheep.

Processing methods such as steam-flaking and reconstitution have been effective in raising sorghum digestibility for cattle to near that of corn (Rooney and Pflugfelder 1986; Theurer et al. 1999) and it is possible that similar benefits may occur for 
sheep. A relatively new method of processing is the expansion technique where a feed is exposed to hydrothermal and mechanical energy treatment before being produced as a granulate (Ziggers 2003). While cracking disrupts the seed coat and increases surface area for digestion, expansion also separates and disrupts starch granules and causes gelatinisation of starch.

The uncertainty about the actual rumen and total-tract digestibility of whole and processed sorghum grain for sheep impedes the determination of the quantities of additional rumen-degradable protein (RDP) and rumen-undegradable protein (UDP) sources required to provide a balanced diet to meet animal growth targets. In a review by Jones et al. (2004), it was concluded that provision of additional proteins specifically to provide UDP would be unnecessary in grainfinishing diets for $35-\mathrm{kg}$ lambs, since the microbial protein synthesised from providing adequate RDP would be more than sufficient to meet tissue requirements. The most cost-effective source of additional RDP is generally a combination of urea and ammonium sulfate. However, large proportions of these nonprotein $\mathrm{N}$ sources may cause the concentrate to become unpalatable and risk causing toxicity if not mixed well and introduced gradually. In addition, there are difficulties in application, with dry urea and ammonium sulfate tending to settle out of the grain mix and concerns that liquid applications may result in volatilisation of non-protein $\mathrm{N}$ over time.

The present study compared growth and carcass characteristics for crossbred lambs consuming several simple, sorghum-based diets. These included a comparison of whole grain with two methods of sorghum processing (cracking and expanding) and the investigation of various sources of additional $\mathrm{N}$ for sorghum diets. A review including some aspects of this data has appeared elsewhere (Bowen et al. 2006).

\section{Materials and methods}

\section{Animal management and experimental design}

In total, 348 Poll Dorset $\times$ Merino wether lambs were used in the experiment, which was conducted at Rosebank Research Station near Longreach, Queensland. The lambs had been shorn and weaned $\sim 3.5$ months earlier and were $\sim 12$ months old at the commencement of the experiment. The lambs were exposed to small amounts of wheaten hay and sorghum grain (up to $25 \mathrm{~g}$ /animal.day) in the paddock over the 3 weeks before feedlot entry. All lambs were examined to ensure the absence of permanent incisors and were drenched for internal parasites (Genesis drench with selenium, Ancare Australia Pty Ltd, Kingsgrove, NSW) and vaccinated against clostridial disease and scabby mouth (Glanvac 6, CSL Ltd, Parkville, Vic.).

The 348 lambs were stratified on liveweight and allocated at random from within the liveweight strata to 19 groups, including one group of nine lambs and 18 groups of 18-19 lambs. The group of nine lambs formed an initial slaughter group, which provided baseline carcass data across the weight range at the start of the experiment. The remaining 18 groups were allocated at random to pens, and the pens to six dietary treatments, such that there were three pens per treatment, thus forming a completely randomised design. After 41 and 56 days on feed, two lambs from each pen were slaughtered to provide intermediate carcass data. These lambs were selected by stratifying each pen on allocation (feedlot entry) weight and selecting the 4th and 16th heaviest lambs for the 41-day slaughter group and 5th and 15 th heaviest lambs for the 56-day slaughter group, so that the average allocation weight of the two lambs selected would be similar to the average for the pen. The remaining lambs were slaughtered after 76 days on feed. The experiment was approved by the Department of Primary Industries and Fisheries (DPI\&F) Animal Ethics Committee.

\section{Treatments and diets}

The lambs were offered wheaten hay ad libitum and one of six concentrate diets, also offered ad libitum. The hay was provided as whole bales in hay racks while the concentrate was provided in troughs and fed daily at 0800 hours. Concentrate treatments were: (1) whole sorghum grain (WS), (2) whole sorghum grain + urea and ammonium sulfate (WS+U), (3) cracked sorghum grain + urea and ammonium sulfate $(\mathrm{CS}+\mathrm{U})$, (4) expanded sorghum grain + urea and ammonium sulfate (ES+U), (5) whole sorghum grain + cottonseed meal (WS $+\mathrm{CSM}$ ), and (6) whole sorghum grain + whole cottonseed (WS + WCS).

In addition, all diets contained limestone, salt and molasses at the rates of 14,21 and $20 \mathrm{~g} / \mathrm{kg} \mathrm{DM}$, respectively and were mixed in a conical auger mixer. Treatment diets 2-5 were formulated with the intention of being isonitrogenous. Concentrated U solution (1-kg solids in $1.5 \mathrm{~L}$ of water; urea: ammonium sulfate ratio of $4.85: 1$ ) was sprayed on to the concentrate mix for diets 2-4 during mixing, with mixing occurring every 2-3 days. Sorghum grain used in treatment 5 was expanded using an Amandus Kahl OE30-2 expander (Better Blend Stockfeeds, Oakey, Qld). Treatment 6 had WCS added to the concentrate mix at the maximum recommended rate (Department of Primary Industries and Fisheries 2006) of $200 \mathrm{~g} / \mathrm{kg}$ total estimated diet DM (assuming lambs would consume the concentrate at $700 \mathrm{~g} / \mathrm{kg}$ of their total diet DM).

Lambs were introduced to their treatment diets gradually over the first 14 days at a rate of $50 \mathrm{~g}$ /animal.day so that by day 14 the sheep were offered $700 \mathrm{~g}$ /animal.day of concentrate. From day 14 the quantity of concentrate on offer was increased gradually until lambs were consuming ad libitum concentrate by day 16-18.

\section{Experimental procedures}

For each pen, concentrate intake was recorded daily and a subsample of concentrate residue was stored in a refrigerator before chemical analyses. Additionally, the DM content of the concentrate residue from each pen was determined at periodic intervals (a total of 13 occasions) to provide an average for the feedlot period. After rain events, the DM content of individual pen residue was determined daily. Each time concentrate diets were mixed, subsamples of each diet and its component feed sources were taken for chemical analyses. The DM content of both the concentrate diets and their component feed sources was determined at weekly intervals. The particle-size distribution of the WS and CS was determined twice during the experiment on representative subsamples of $1 \mathrm{~kg}$ each. The grain was passed through three sieves of pore size $2.75,2.00$ and $1.50 \mathrm{~mm}^{2}$ in sequence, by shaking 100 times on each sieve size. 
The loss of $\mathrm{N}$ from sorghum grain treated with $\mathrm{U}$ solution was determined twice: once during the feedlot period in August and once during hotter ambient temperatures in November after the feedlot period was complete. On each occasion, $15 \mathrm{~kg}$ of concentrate diet $\mathrm{WS}+\mathrm{U}$ was placed into a galvanised iron, poultry self-feeder to simulate a sheep self-feeder. After mixing of the concentrate diet and addition to the self-feeder, one seventh of the concentrate was removed on each of the following 7 days. A subsample of the concentrate immediately following mixing, as well as the concentrate removed on each day, was stored in the refrigerator awaiting analysis for $\mathrm{N}$ content.

Lambs were weighed once weekly at 1400 hours. Only those lambs in the final, 76-day slaughter group were used in the determination of liveweight change over time. Rumen fluid and faecal samples were collected from lambs after 15 or 16 days on feed (start of the ad libitum concentrate feeding period) and after 59 days on feed. One bulk faecal sample was collected from the lambs in each pen while rumen fluid samples were collected from three randomly selected animals per pen. Sampling was conducted over a maximum of $6 \mathrm{~h}$ on each day ranging from 3.5 to $10 \mathrm{~h}$ after morning feeding. Due to the length of time required, sampling of pens was staggered across treatment groups. A stomach tube connected to a $60-\mathrm{mL}$ syringe was used to extract $\sim 120 \mathrm{~mL}$ of rumen fluid per lamb. The $\mathrm{pH}$ of the rumen fluid was determined immediately after collection using a portable $\mathrm{pH}$ meter or $\mathrm{pH}$ indicator strips, fluid was then strained and concentrated sulfuric acid was added to reduce $\mathrm{pH}$ below 3. A subsample was placed on ice and later frozen before analysis for ammonia-N concentration. Faecal samples were collected per rectum, placed on ice and later frozen awaiting analysis for starch content.

Prior to slaughter, the lambs were taken off feed and weighed immediately at 1400 hours (liveweight before transport). Lambs were transported $860 \mathrm{~km}(\sim 10-12 \mathrm{~h})$ and slaughtered according to standard abattoir protocol in Miles, Queensland. Lambs in the 0,41 and 56-day slaughter groups were slaughtered $\sim 1.5-2$ days after removal from feed. The 76-day slaughter group was slaughtered over 2 days ( $\sim 1.5-3$ days after removal from feed) with half the lambs from each pen, selected on stratified liveweight, killed on each day. Hot carcass weight (excluding the kidneys and other internal organs) was recorded. Dressing percentage was calculated as hot carcass weight divided by liveweight before trucking. Fat depth $(\mathrm{mm})$ was determined on the hot carcass at the GR site, located over the $12 \mathrm{th}$ rib, $110 \mathrm{~mm}$ from the mid-line of the carcass.

\section{Analytical procedures}

DM content of the feed samples was determined by drying to a constant weight at $100^{\circ} \mathrm{C}$ in a forced draught oven. Samples were milled to $<1 \mathrm{~mm}$ before chemical analysis. The ash content was determined by heating dry samples in an electric muffle furnace (Thermogravimetric analyser TGA-601, LECO Corporation, St Joseph, MI) at $610^{\circ} \mathrm{C}$ to constant weight under an atmosphere of oxygen. Feed samples were analysed for total $\mathrm{N}$ content by a combustion method (Sweeney 1989) using an Elementar RapidN analyser (Elementar analysensysteme $\mathrm{GmbH}$, Hanau, Germany). Ash-free neutral detergent fibre and ash-free acid detergent fibre content in wheaten hay samples were determined by the method of Van Soest and Wine (1967) and Van Soest (1963), respectively, adapted for the Fibretec 2021 Fibrecap system developed by Foss Tecator (Foss Tecator 2002a, 2002b). Crude fibre (CF) content in concentrate feed ingredients and concentrate diets was determined by the method of AOAC (1975) adapted for the Fibretec 2021 Fibrecap System by Foss Tecator (Foss Tecator 2002c). Ether extract (EE) or crude fat content in concentrate feed ingredients and concentrate diets was determined by soxhlet extraction using petroleum ether (boiling range $40-60^{\circ} \mathrm{C}$ ) for $16 \mathrm{~h}$ (Kent-Jones and Amos 1957). The starch content of feeds and faeces was determined by conversion of starch to glucose using a two-step enzyme treatment followed by colourimetric determination with a glucose oxidase/peroxidase reagent. All enzymes and reagents were supplied in kit form from Megazyme available from Deltagen Australia (Boronia, Vic.). The enzymatic breakdown of the starch using a heat stable $\alpha$-amylase and amyloglucosidase is based on the procedure of McCleary et al. (1992). Prior to determination of rumen ammonia-N concentration, rumen fluid was shaken and then centrifuged (2600 $\mathrm{g}$ for $12 \mathrm{~min}$ ) to obtain a clear supernatant. After a reaction, which converts ammonia to form an indophenol dye (Bolleter et al. 1961), spectrophotometric determination was conducted on an Olympus AU400 clinical analyser (Olympus, Mount Waverley, Vic.).

\section{Calculations}

The metabolisable energy (ME) content of wheaten hay was predicted using Eqn 67 (Anon. 1975) with a correction for ash content:

$$
\begin{gathered}
\mathrm{ME}(\mathrm{MJ} / \mathrm{kg} \mathrm{DM})=13.5-[0.015 \text { acid detergent fibre }(\mathrm{ADF}) \\
+0.015 \mathrm{ash}]+0.014 \text { crude protein }(\mathrm{CP})
\end{gathered}
$$

where all analyses are in $\mathrm{g} / \mathrm{kg} \mathrm{DM}$.

The ME content of sorghum grain, WCS, CSM and the concentrate diets was predicted using Eqn 75 (Anon. 1975):

$$
\begin{aligned}
\mathrm{ME}(\mathrm{MJ} / \mathrm{kg} \mathrm{DM})= & 0.012 \mathrm{CP}+0.031 \mathrm{EE}+0.005 \mathrm{CF} \\
& +0.014 \mathrm{NFE}
\end{aligned}
$$

where NFE (nitrogen free extract $)=1000-(\mathrm{CP}+\mathrm{EE}+\mathrm{CF}+$ ash), and all analyses are in $\mathrm{g} / \mathrm{kg} \mathrm{DM}$.

The CP content in the concentrate actually consumed (i.e. taking into account the different $\mathrm{CP}$ concentrations in the concentrate offered $v$. that refused) was calculated for each pen as:

$$
\begin{gathered}
\mathrm{CP} \text { content }(\mathrm{g} / \mathrm{kg} \mathrm{DM})=[(\mathrm{CP} \text { in concentrate offered }(\mathrm{g} / \text { day }) \\
-\mathrm{CP} \text { in concentrate refused }(\mathrm{g} / \text { day })] / \\
\text { actual concentrate intake }(\mathrm{kg} / \text { day })
\end{gathered}
$$

A similar calculation was used to determine ME content of the concentrate consumed $(\mathrm{MJ} / \mathrm{kg} \mathrm{DM})$.

\section{Statistical analyses}

The statistical package, GENSTAT for Windows, 8th edition (GENSTAT Committee 2005), was used for all statistical analyses. The data were subjected to ANOVA in a completely randomised design with the pen as the experimental unit. Pairwise differences between means were tested using a protected 1.s.d. procedure $(P=0.05)$. The rumen and faecal data recorded after 15-16 and 59 days of feeding were analysed separately and the combined data analysed as a split-plot with time as the 
subfactor. Log-transformations of rumen ammonia-N concentrations were analysed to stabilise the variance and satisfy the assumptions of the ANOVA. The effect of day of slaughter for the 76-day slaughter group was investigated by using 'day of slaughter' as a covariate in the ANOVA for carcass weight, dressing percentage and fat depth. The covariate was not significant for carcass weight and dressing percentage but was significant for fat depth which was adjusted accordingly. The number of slaughtered lambs which had developed permanent incisor teeth at 41, 56 and 76 days were analysed by fitting generalised linear models assuming a binomial error distribution with a logit link function.

The carcass weights of lambs slaughtered after 76 days on feed were estimated for 0,41 and 56 days on feed using their individual liveweight at those times and the average dressing percentages of the intermediate kill groups. The days to reach a carcass weight of $18 \mathrm{~kg}$ were then predicted by fitting linear regression equations for each lamb to the estimated carcass weights after 0,41 and 56 days on feed and to actual carcass weights after 76 days on feed. Some lambs did not reach $18-\mathrm{kg}$ carcass weight within the 76 days and hence the time to reach a carcass weight of $18 \mathrm{~kg}$ was only known to be greater than 76 days and was said to be censored. The censored times were replaced by estimated values, using the method of Taylor (1973).

Liveweight data were also analysed by residual maximum likelihood (REML) as a linear mixed model with fixed effects (treatment $\times$ days on feedlot) and random effects (pen + pen $\times$ days on feedlot), including cubic spline terms in the random model and with unrestricted correlated errors. To investigate the nonlinear patterns for treatments over time, differences in deviances were calculated between the following: linear random coefficient regression model, a random coefficient regression model with a common random cubic term over time, and a random coefficient regression model with separate random cubic terms for each treatment combination over time. Linear growth rates were then analysed over 0-76, 25-56 and 56-76 days of feeding, with and without initial weights as covariates. Initial weights were not significant.

\section{Results}

The chemical composition of feed ingredients and the concentrate diets offered during the post-introductory period as well as the ME and $\mathrm{CP}$ content of the concentrate actually consumed by the lambs is given in Table 1 .

Tests of average particle size distribution of WS and CS showed that the greatest proportion of WS (0.92) had particles $>2.75 \mathrm{~mm}^{2}$, while the greatest proportion of CS $(0.56)$ had particles between 2.00 and $2.75 \mathrm{~mm}^{2}$ with only 0.15 of CS having particles $>2.75 \mathrm{~mm}^{2}$.

The average maximum temperature over the 7 days of testing for loss of $\mathrm{N}$ from the $\mathrm{WS}+\mathrm{U}$ diet when placed in a galvanised iron self-feeder was 25.6 and $38.9^{\circ} \mathrm{C}$ during the periods of medium and high ambient temperatures, respectively. There was an inconsistent pattern of CP concentration over time for both temperature periods (Fig. 1). The average concentrate $\mathrm{CP}$ over the 7 days of sampling during the period of medium ambient temperature was equivalent to that straight after mixing: $174 \mathrm{~g} / \mathrm{kg}$ DM. During the period of high ambient temperature, the average CP concentration over the 7 days of sampling $(171 \mathrm{~g} / \mathrm{kg} \mathrm{DM})$ was lower than that straight after mixing $(181 \mathrm{~g} / \mathrm{kg} \mathrm{DM})$. This appears to be a result of uneven mixing and subsampling error rather than due to a gradual loss of $\mathrm{N}$.

Table 1. Dry matter (DM) content (g/kg, as fed), predicted metabolisable energy (ME, MJ/kg DM) and concentration (g/kg DM) of crude protein (CP), organic matter (OM), neutral detergent fibre (NDF), acid detergent fibre (ADF), crude fibre (CF), starch and ether extract (EE) in feed ingredients, the concentrate diets offered and that actually consumed by lambs (mean \pm s.e.) after day 14 Treatment descriptions are given in the text

\begin{tabular}{|c|c|c|c|c|c|c|c|c|c|}
\hline & $\mathrm{DM}$ & $\mathrm{ME}$ & $\mathrm{CP}$ & $\mathrm{OM}$ & $\mathrm{NDF}$ & $\mathrm{ADF}$ & $\mathrm{CF}$ & Starch & $\mathrm{EE}$ \\
\hline \multicolumn{10}{|l|}{ Feed ingredients } \\
\hline Wheaten hay & 905 & 6.0 & 74.4 & 908 & 700 & 474 & - & - & - \\
\hline Whole sorghum grain & 890 & 14.0 & 130 & 988 & - & - & 19 & 690 & 35 \\
\hline Cracked sorghum grain & 885 & 14.0 & 130 & 988 & - & - & 17 & 689 & 35 \\
\hline Expanded sorghum grain & 871 & 13.8 & 130 & 979 & - & - & 23 & 683 & 35 \\
\hline Cottonseed meal & 915 & 11.3 & 509 & 927 & - & - & 111 & - & 19 \\
\hline Whole cottonseed & 899 & 13.9 & 206 & 962 & - & - & 268 & - & 194 \\
\hline Molasses & 752 & - & 80.6 & 872 & - & - & - & - & - \\
\hline \multicolumn{10}{|l|}{ Concentrate offered } \\
\hline WS & 890 & 13.6 & 122 & 955 & - & - & 14 & 645 & 37 \\
\hline $\mathrm{WS}+\mathrm{U}$ & 867 & 13.6 & 166 & 964 & - & - & 21 & 648 & 35 \\
\hline $\mathrm{CS}+\mathrm{U}$ & 857 & 13.5 & 171 & 960 & - & - & 17 & 622 & 34 \\
\hline $\mathrm{ES}+\mathrm{U}$ & 841 & 13.3 & 180 & 948 & - & - & 19 & 633 & 33 \\
\hline WS+CSM & 887 & 13.5 & 174 & 963 & - & - & 27 & 566 & 33 \\
\hline WS+WCS & 893 & 13.4 & 154 & 930 & - & - & 108 & 406 & 99 \\
\hline \multicolumn{10}{|l|}{ Concentrate consumed } \\
\hline WS & - & $13.7 \pm 0.07$ & $122 \pm 0.4$ & - & - & - & - & - & - \\
\hline $\mathrm{WS}+\mathrm{U}$ & - & $13.6 \pm 0.08$ & $163 \pm 1.1$ & - & - & - & - & - & - \\
\hline $\mathrm{CS}+\mathrm{U}$ & - & $13.9 \pm 0.02$ & $165 \pm 1.0$ & - & - & - & - & - & - \\
\hline $\mathrm{ES}+\mathrm{U}$ & - & $13.5 \pm 0.09$ & $171 \pm 2.4$ & - & - & - & - & - & - \\
\hline $\mathrm{WS}+\mathrm{CSM}$ & - & $13.9 \pm 0.06$ & $162 \pm 2.2$ & - & - & - & - & - & - \\
\hline WS+WCS & - & $13.4 \pm 0.04$ & $145 \pm 1.7$ & - & - & - & - & - & - \\
\hline
\end{tabular}




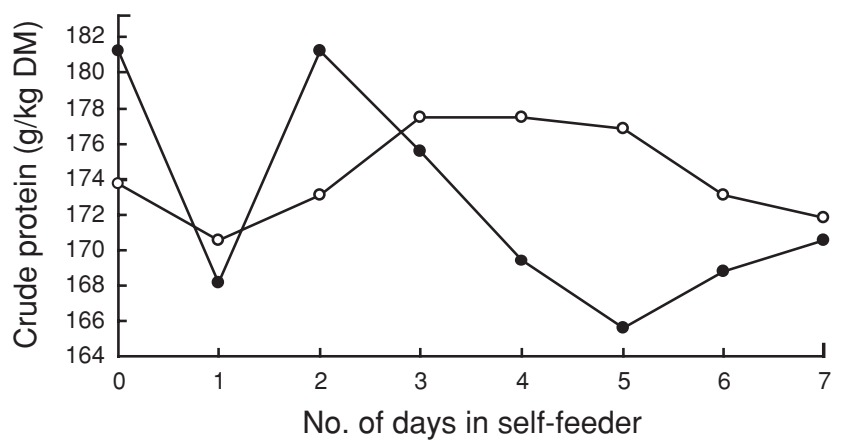

Fig. 1. Concentration of crude protein over time for sorghum grain treated with urea and ammonium sulfate and stored in a galvanised iron self-feeder over periods of medium $(\bigcirc)$ and high $(\bullet)$ ambient temperature.

The lambs consumed both the hay and concentrate components of their diet very readily during the introductory period, and ate all concentrate that was offered. In the 14-day period immediately following the introductory feeding period, large fluctuations in daily concentrate intake occurred for all treatments (minimum and maximum pen intake 169 and $1213 \mathrm{~g} \mathrm{DM} /$ animal.day, respectively), with two major depressions occurring over days 19-22 and 25-28 of feeding. After the second depression, concentrate intake gradually increased and the daily fluctuations in concentrate intake were smaller. Average concentrate intake by lambs after the introductory feeding period was significantly $(P<0.05)$ lower for the WS diet than for all other treatment diets (Table 2). For diets with added non-protein $\mathrm{N}$ (U), cracking or expanding sorghum grain did not significantly increase concentrate intake above that for WS. In addition, for WS diets, replacing nonprotein $\mathrm{N}$ with sources of true protein (CSM or WCS) did not significantly increase concentrate intake.

Lambs consuming all treatment diets followed the same general pattern of liveweight change over time (Fig. 2). The
REML analyses showed that a random cubic spline over time should be included to model common deviations about the linear trend but that fitting separate splines for each treatment did not provide a significant improvement. The Wald statistics for day and treatment $\times$ day were significant $(P<0.001$ and $P=0.044$, respectively). Days $1-3$ and $10-25$ on feed were periods of poor weight gain. After this period, liveweight gain was relatively linear, with the highest rate of liveweight gain during the period of 25-56 days on feed, averaging $236 \mathrm{~g} /$ animal.day across all treatment groups and as high as $252 \mathrm{~g} /$ animal.day for the ES+U treatment (Table 2). However, the overall rate of liveweight change for the period 0-76 days on feed was much lower with an average of $176 \mathrm{~g} /$ animal.day across all treatment groups. There were no significant differences between treatments for initial or final liveweight or for liveweight change.

The 76-day carcass weight and carcass fat depth of lambs fed WS were significantly lower $(P<0.05)$ than for all other treatment groups except $\mathrm{WS}+\mathrm{U}$ while days required on feed to reach 18 -kg carcass weight were significantly greater for lambs consuming the WS concentrate than for all other concentrate diets (Table 2). Neither cracking nor expanding WS with added non-protein $\mathrm{N}$ resulted in significantly increased carcass weights or in significantly reduced days to $18 \mathrm{~kg}$ carcass weight for lambs, although carcass fat depth was significantly increased compared with the whole sorghum plus non-protein $\mathrm{N}$ diet. There was no effect of source of additional $\mathrm{N}$ on lamb carcass weight. However, carcass fat depth was significantly increased when true protein sources were added to whole sorghum diets rather than non-protein $\mathrm{N}$, with $\mathrm{WS}+\mathrm{CSM}$ also producing a significantly greater fat depth than for WS+WCS. The WS+CSM diet, but not the WS+WCS diet, significantly reduced days to $18 \mathrm{-kg}$ carcass weight compared with $\mathrm{WS}+\mathrm{U}$. There were no treatment effects on dressing percentage.

Average lamb carcass weight for treatment groups after 76 days on feed was related to average daily concentrate DM

Table 2. Concentrate intake, liveweight and carcass characteristics for lambs finished on one of six treatment diets over 76 days

Values are means; average standard error of difference (s.e.d.) is presented. Treatment descriptions are given in the text. Values within rows followed by different letters are significantly different at $P=0.05$

\begin{tabular}{|c|c|c|c|c|c|c|c|c|}
\hline & WS & $\mathrm{WS}+\mathrm{U}$ & $\mathrm{CS}+\mathrm{U}$ & $\begin{array}{c}\text { Treatment } \\
\text { ES+U }\end{array}$ & $\mathrm{WS}+\mathrm{CSM}$ & WS+WCS & Average s.e.d. & $\begin{array}{c}\text { Overall feedlot } \\
\text { mean }\end{array}$ \\
\hline $\begin{array}{l}\text { Concentrate intake days } 15-76 \\
\text { (g dry matter/animal.day) }\end{array}$ & $800 \mathrm{a}$ & $916 \mathrm{bc}$ & $894 b$ & $985 \mathrm{c}$ & $968 \mathrm{bc}$ & $959 b c$ & 40.7 & 920 \\
\hline \multicolumn{9}{|l|}{ Liveweight $(\mathrm{kg})$} \\
\hline 0 days & 35.4 & 36.0 & 36.0 & 35.6 & 35.9 & 35.3 & 0.51 & 35.7 \\
\hline 76 days & 46.3 & 47.9 & 48.0 & 49.1 & 49.7 & 49.0 & 1.09 & 48.4 \\
\hline \multicolumn{9}{|c|}{ Liveweight change (g/animal.day) ${ }^{\mathrm{A}}$} \\
\hline $0-76$ days & 149 & 170 & 172 & 187 & 190 & 190 & 15.5 & 176 \\
\hline $25-56$ days & 201 & 226 & 242 & 252 & 245 & 249 & 34.3 & 236 \\
\hline $56-76$ days & 125 & 146 & 135 & 153 & 140 & 108 & 45.5 & 134 \\
\hline Carcass weight $(\mathrm{kg})$ & $20.0 \mathrm{a}$ & $20.9 \mathrm{ab}$ & $21.1 \mathrm{~b}$ & $21.7 \mathrm{~b}$ & $21.8 \mathrm{~b}$ & $21.4 \mathrm{~b}$ & 0.44 & 21.1 \\
\hline Dressing percentage & 43.1 & 43.5 & 43.7 & 44.2 & 43.8 & 43.7 & 0.56 & 43.7 \\
\hline Fat depth $(\mathrm{mm})^{\mathrm{B}}$ & $11.8 \mathrm{a}$ & $12.9 \mathrm{a}$ & $14.2 \mathrm{~b}$ & $14.7 \mathrm{~b}$ & $15.9 \mathrm{c}$ & $14.3 \mathrm{~b}$ & 0.48 & 14.0 \\
\hline Days to $18-\mathrm{kg}$ carcass weight ${ }^{\mathrm{C}}$ & $55.8 \mathrm{a}$ & $46.0 \mathrm{bc}$ & $47.0 \mathrm{~b}$ & $39.9 \mathrm{~cd}$ & $36.7 \mathrm{~d}$ & $44.6 \mathrm{bc}$ & 3.20 & 45.0 \\
\hline
\end{tabular}

${ }^{A}$ Change in liveweight was determined from linear regressions fitted to liveweight points within each period for lambs in the 76-day slaughter group only.

${ }^{\mathrm{B}}$ Means adjusted for day of slaughter.

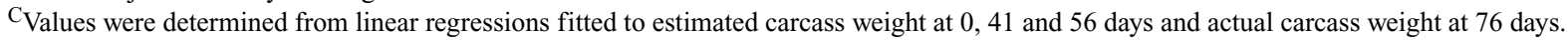




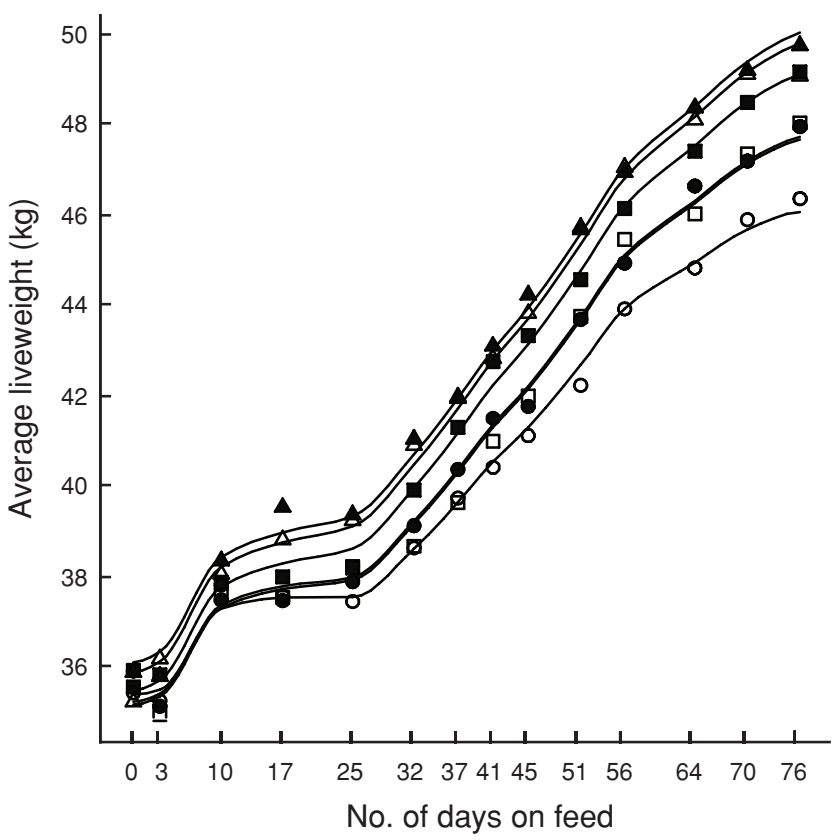

Fig. 2. Change in lamb liveweight over the feedlot period as illustrated by the spline curves from residual maximum likelihood analysis. Values are the treatment means for lambs in the 76-day slaughter group only: WS $(O)$, $\mathrm{WS}+\mathrm{U}(\bullet), \mathrm{CS}+\mathrm{U}(\square), \mathrm{ES}+\mathrm{U}(\boldsymbol{\square}), \mathrm{WS}+\mathrm{CSM}(\boldsymbol{\Delta})$ and WS+WCS $(\triangle)$. Treatment descriptions are given in the text.

intake over the post-introductory feeding period (Fig. 3). The linear regression accounted for $93 \%$ of the variation, although the point for WS $(800,20)$ had high leverage. There was a weaker relationship between concentrate DM intake over the post-introductory feeding period and $\mathrm{CP}$ content in the concentrate with the point for WS again having high leverage on the linear regression (Equation: $y=487$ (s.e. 144.0) +2.69 (s.e. 0.889) $x$, adjusted $r^{2}=0.62, P=0.039$ ).

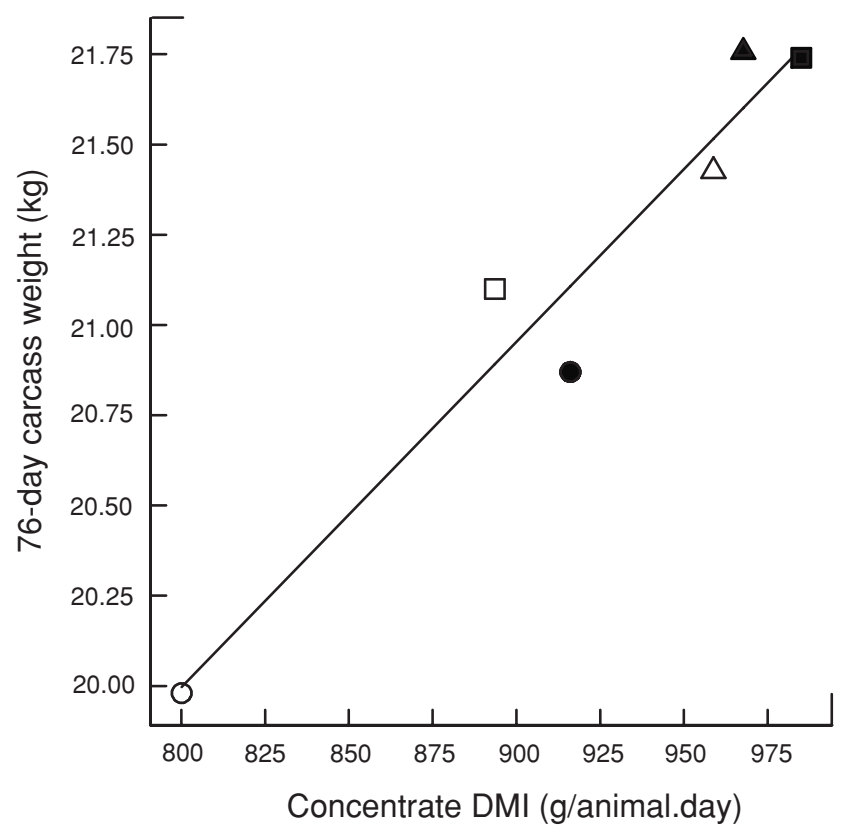

Fig. 3. Relationship between lamb carcass weight after 76 days of feeding and average concentrate dry matter intake (DMI) over the post-introductory feeding period. Equation of the line is: $y=12.3$ (s.e. 1.11) +0.0096 (s.e. 0.00120)x (adjusted $r^{2}=0.93, P=0.001$ ). Values are the treatment means for lambs in the 76-day slaughter group only: WS $(\bigcirc)$, WS+U $(\bullet)$, $\mathrm{CS}+\mathrm{U}(\square), \mathrm{ES}+\mathrm{U}(\boldsymbol{\square})$, WS $+\mathrm{CSM}(\boldsymbol{\Delta})$ and WS+WCS $(\triangle)$ ). Treatment descriptions are given in the text.

Compared with samples taken after 15-16 days on feed, samples after 59 days had significantly higher $(P<0.05)$ rumen fluid $\mathrm{pH}$, lower rumen ammonia- $\mathrm{N}$ and higher faecal starch concentrations (Table 3 ). There were no treatment effects on rumen fluid $\mathrm{pH}$ after $15-16$ days on feed. However, after 59 days on feed, lambs consuming the $\mathrm{CS}+\mathrm{U}$ diet had significantly lower rumen fluid $\mathrm{pH}$ than for all other treatment groups except

Table 3. Effect of treatment diet on $\mathrm{pH}$ and $\log _{10}$ ammonia- $\mathrm{N}\left(\mathrm{NH}_{3}-\mathrm{N}\right)$ concentration in rumen fluid, and on starch concentration in faeces for lambs consuming six treatment diets

Values are means; average standard error of difference (s.e.d.) is presented. Treatment descriptions are given in the text. Values within rows followed by different lowercase letters are significantly different at $P=0.05$; feedlot means for different times of sampling followed by different uppercase letters are significantly different at $P=0.05$

\begin{tabular}{|c|c|c|c|c|c|c|c|c|}
\hline \multirow[t]{2}{*}{ Days on feed } & \multicolumn{7}{|c|}{ Treatment } & \multirow{2}{*}{$\begin{array}{c}\text { Overall feedlot } \\
\text { mean }\end{array}$} \\
\hline & WS & $\mathrm{WS}+\mathrm{U}$ & $\mathrm{CS}+\mathrm{U}$ & $\mathrm{ES}+\mathrm{U}$ & $\mathrm{WS}+\mathrm{CSM}$ & WS+WCS & Average s.e.d. & \\
\hline \multicolumn{9}{|c|}{ Rumen fluid $p H$} \\
\hline 15-16 days & 5.9 & 6.1 & 5.8 & 5.6 & 6.1 & 6.2 & 0.305 & $5.9 \mathrm{~A}$ \\
\hline 59 days & $6.5 b$ & $6.3 \mathrm{ab}$ & $6.1 \mathrm{a}$ & $6.6 b$ & $6.3 \mathrm{ab}$ & $6.6 \mathrm{~b}$ & 0.143 & $6.4 \mathrm{~B}$ \\
\hline \multicolumn{9}{|c|}{ Rumen $\mathrm{NH}_{3}-\mathrm{N}$} \\
\hline $15-16$ days ( $\log _{10}$ transformed) & $3.44 \mathrm{a}$ & $4.42 \mathrm{~b}$ & $5.30 \mathrm{c}$ & $5.33 \mathrm{c}$ & $4.72 \mathrm{bc}$ & $4.09 \mathrm{ab}$ & 0.322 & $4.55 \mathrm{~A}$ \\
\hline $15-16$ days $(\mathrm{mg} / \mathrm{L})^{\mathrm{A}}$ & $(31.0)$ & $(83.2)$ & (200.9) & $(206.8)$ & $(112.2)$ & $(59.4)$ & & $(94.5)$ \\
\hline 59 days ( $\log _{10}$ transformed) & 3.71 & 4.10 & 4.54 & 4.51 & 3.88 & 3.87 & 0.283 & $4.10 \mathrm{~B}$ \\
\hline 59 days $(\mathrm{mg} / \mathrm{L})^{\mathrm{A}}$ & $(40.8)$ & $(60.4)$ & $(93.8)$ & $(91.1)$ & $(48.6)$ & $(48.0)$ & & $(60.5)$ \\
\hline \multicolumn{9}{|c|}{ Faecal starch (g/kg dry matter) } \\
\hline 15-16 days & $158 \mathrm{a}$ & $144 \mathrm{a}$ & $115 \mathrm{ab}$ & $77 b$ & $147 \mathrm{a}$ & $143 a$ & 21.4 & $131 \mathrm{~A}$ \\
\hline 59 days & $192 \mathrm{a}$ & $184 \mathrm{a}$ & $193 \mathrm{a}$ & $79 b$ & $182 \mathrm{a}$ & $217 \mathrm{a}$ & 33.3 & $175 B$ \\
\hline
\end{tabular}

\footnotetext{
${ }^{\mathrm{A}}$ Untransformed values $(\mathrm{mg} / \mathrm{L})$ are in parentheses.
} 
$\mathrm{WS}+\mathrm{U}$ and WS+CSM. After 15-16 days on feed, rumen ammonia-N concentrations were significantly lower for lambs consuming WS than for all other treatments except WS+WCS. Cracking or expanding WS with added non-protein N resulted in a significant increase in rumen ammonia- $\mathrm{N}$ concentrations after 15-16 days on feed compared with WS plus non-protein N, but replacing non-protein $\mathrm{N}$ with sources of true protein did not. There was weaker evidence $(P=0.051)$ of differences in rumen ammonia-N concentration among treatments after 59 days on feed with concentrations for $\mathrm{CS}+\mathrm{U}$ and $\mathrm{ES}+\mathrm{U}$ tending to be greater than for WS, WS+CSM and WS+WCS. Faecal starch concentrations were significantly lower for animals consuming the ES+U diet than for all other treatments after both 15-16 and 59 days on feed, apart from the $\mathrm{CS}+\mathrm{U}$ treatment after $15-16$ days on feed.

Although no permanent incisor teeth had erupted in any lambs at the commencement of feedlotting, a proportion developed permanent incisors during the feedlot period. Treatment had no significant effect on the number of lambs that developed permanent incisors. After 41 days and 56 days on feed 16.7 (s.e. 6.00$) \%$ and 36.1 (s.e. 7.26 ) $\%$, respectively, of the 36 lambs slaughtered on each occasion had erupted incisors, while after 76 days on feed 38.4 (s.e. 2.96)\% of the 267 lambs slaughtered had erupted incisors.

\section{Discussion}

The comparison of WS with CS and ES and the investigation of various sources of additional $\mathrm{N}$ for inclusion in sorghum diets for lambs were conducted in this study under practical feeding conditions where hay and grain were provided separately to reflect current industry practice. Under these conditions, all concentrate diets based on sorghum grain supported an increase in carcass weight of crossbred lambs above the threshold value of $18 \mathrm{~kg}$, which is commonly preferred for the domestic market (Meat and Livestock Australia 2005). In this study, the carcass weight of lambs was related to the daily intake of concentrate. The 18- $\mathrm{kg}$ target carcass weight was achieved in less than 40 days on feed for the WS+CSM and the ES+U diets and in 45-47 days for other sorghum diets containing an additional $\mathrm{N}$ source (WS+WCS, WS+U and CS+U). Lambs consuming the WS diet without any additional $\mathrm{N}$ (WS) required a much longer period of feeding (56 days) to achieve the target carcass weight.

Neither cracking nor expanding WS with the inclusion of non-protein $\mathrm{N}$ resulted in significantly increased final liveweight, growth rates or carcass weights for crossbred lambs although carcass fat depth was significantly increased. Similarly, Davis (1977) reported that dry-rolling sorghum grain had no effect on overall lamb liveweight gain compared with whole grain. This result is similar to that widely reported for other cereal grains (mainly barley, wheat, oats and maize) where it has been concluded that processing grain for sheep is likely to be of no value and in many circumstances can cause negative effects in giving rise to acidosis, rumenitis and inhibition of cellulose digestion (Ørskov 1979). Furthermore, reviews by Rowe et al. (1999) and Beretta and Kirby (2004) indicated that the whole-tract digestibility of cereal starch by sheep approaches $100 \%$ for common feed grains, suggesting that there is limited potential for improving digestion through processing. This situation is in contrast to that for cattle where the benefits of processing, in increasing digestion of cereal grains, have been well documented (e.g. review by Huntington 1997), with steam processing producing better results than dry rolling and with sorghum having the most dramatic response to processing of all grains. The ability of sheep to better masticate grains, in addition to differences in particle flow dynamics through the digestive tract, have been suggested as the reasons for the differences in response to processing for sheep compared with cattle (Rowe et al. 1999).

Although expanding sorghum grain significantly reduced faecal starch concentrations compared with WS or CS diets with added non-protein $\mathrm{N}$, indicating improved starch digestion, this did not result in significant differences in growth or carcass characteristics. Although not statistically significant $(P>0.05)$, the reduction in time required on feed by 6 days for lambs consuming the ES diet compared with the whole sorghum diet plus non-protein $\mathrm{N}$, may have implications commercially when economic parameters are considered.

Concentrate DM intake was not closely related to concentrate $\mathrm{CP}$ content, indicating that $\mathrm{CP}$ was not limiting for rumen microbes, with the possible exception of the WS diet. WS fed without an additional $\mathrm{N}$ source resulted in significantly more days required on feed to reach $18-\mathrm{kg}$ carcass weight than for all diets containing added N. This diet also resulted in significantly lower carcass weight and fat depth than for diets of WS plus true protein. These results appear linked to the significantly lower concentrate intake measured for lambs consuming the WS diet compared with diets containing additional $\mathrm{N}$. If the degradability of $\mathrm{CP}$ in sorghum is assumed to be $45 \%$ (Neutze 1991) then the RDP:ME ratio in the WS concentrate diet would be $4 \mathrm{~g}$ RDP/MJ ME and thus much lower than the ratio of $10 \mathrm{~g} \mathrm{RDP} / \mathrm{MJ} \mathrm{ME}$, which is generally assumed to be optimal for high-grain diets (Jones et al. 2004). It is postulated that the low concentrate CP content for the WS diet $(122 \mathrm{~g} / \mathrm{kg} \mathrm{DM})$ and corresponding low rumen ammonia-N concentrations ( $40.8 \mathrm{mg} / \mathrm{L}$ after 59 days on feed) were less than optimal for the rumen microbes, resulting in the significantly lower voluntary intake and corresponding lower performance of lambs compared with those consuming diets with added $\mathrm{N}$.

Substituting sources of true protein (CSM or WCS) for nonprotein $\mathrm{N}$ sources (U) did not significantly affect concentrate intakes or carcass weights of lambs in this study although carcass fat depth was significantly increased. Our results are in contrast to those reported by Wiese et al. (2003) where crossbred lambs fed cereal grain with lupins and expeller canola meal had significantly higher growth rates than lambs fed an isonitrogenous diet of grain and urea. However, the poor performance of the urea diet in their experiment was attributed to acidosis associated with a lower concentration of effective fibre in the urea diet, rather than to the provision of true protein per se. As there was no apparent loss of N from WS treated with U solution over 7 days in a self-feeder, urea- and ammonium sulfate-treated grain appears suitable for practical application in feedlot diets. Our data are supported by those of Ørskov et al. (1974) who found no loss of $\mathrm{N}$ from urea-treated whole grains after 6 months of storage, and also by Hadjipanayiotou and Georghiades (1985) who found no loss of N in urea-treated triticale grain stored for 42 days. 
Although the concentration of $\mathrm{CP}$ consumed by lambs offered the WS+WCS diet was lower than that for the WS+U and WS+CSM diets (145 g/kg DM v. $163 \mathrm{~g} / \mathrm{kg} \mathrm{DM})$, lambs consuming the WS+WCS diet achieved similar carcass weights to those consuming the higher CP diets. The WS+WCS diet may be an attractive diet for opportunity feedlotters due to the ease of mixing, without requirement for $\mathrm{U}$ application. The WS+CSM diet, although not producing significantly greater final carcass weights, produced significantly greater carcass fat depth and resulted in significantly fewer days to $18-\mathrm{kg}$ carcass weight than either the WS $+\mathrm{U}$ or WS + WCS diets.

There were no significant differences among treatments for liveweight or liveweight change in this experiment although trends in mean treatment liveweight were similar to those for carcass weight. The growth rates of crossbred lambs in this study, measured over 76 days on feed, were within the range of indicative growth rates expected for first cross lambs (150-350 g/day; Bell et al. 2003), although they were at the lower end of the range. Compared with lambs consuming the WS+U diet in our experiment ( $170 \mathrm{~g} /$ day), first cross lambs fed for a shorter time period of 49 days had greater growth rates when fed a winter cereal grain diet with added urea $(180 \mathrm{~g} /$ day; Wiese et al. 2003). Furthermore, first cross lambs fed for 49 days on winter cereal diets with added lupins or canola meal had greater growth rates (233 and $272 \mathrm{~g}$ /day, respectively; Wiese et al. 2003) than lambs fed sorghum-based diets with additional true protein in our experiment $(190 \mathrm{~g} /$ day $)$. However, the growth rates measured in our experiment for lambs fed sorghum-based diets with additional true protein were greater than those measured for Poll Dorset $\times$ Merino wether lambs fed a winter cereal grain and lupins concentrate diet over 71 days $(157 \mathrm{~g} /$ day; McIntyre and Ryan 2005) and were at the higher end of the range of those for lambs fed over 78 days (163-189 g/day; Ryan and McIntyre 2006).

The rate of lamb liveweight gain varied over time in this experiment. There was an initial period of slower liveweight gain from 0 to 25 days on feed, which appeared linked to fluctuating concentrate intakes in the 2 weeks following the introductory feeding period. After the first 25 days on feed, liveweight gain was relatively linear, with the greatest rate of gain during the period of 25-56 days on feed ( $236 \mathrm{~g}$ /day for overall feedlot) after which liveweight gain began to plateau $(134 \mathrm{~g} /$ day for overall feedlot). The efficiency of feed conversion is known to decline with increasing age (Malik et al. 1996), probably due to increasing fat deposition (Jones et al. 2004), and may have been the cause of reduced rates of liveweight gain from day 56 of feeding in our experiment. However, studies by Searle and Graham $(1970,1972)$ found that bodyweight determines the components of growth, age per se being unimportant, with the most extensive phase of fattening beginning at a bodyweight of $\sim 30 \mathrm{~kg}$ in sheep, indicating that the lambs in our trial should have already entered this stage by the commencement of the experiment.

The eruption of permanent incisors during the feeding period for a significant proportion of lambs in this study has economic implications as, in Australia, any evidence of the first permanent teeth results in the carcass being downgraded and classified under AUS-MEAT as hogget (Anon. 2001), with a significant reduction in carcass value. Lambs produced from native pasture systems in rangeland Australia can commonly be 12 months old before they reach the desired feedlot entry weight of $35 \mathrm{~kg}$. Supplementation or removal of lambs at weaning to improved pasture or crop systems may be options to reduce age at feedlot entry. This problem could be potentially negated by a change in the current Australian sheep classification system, as argued for by Wiese et al. (2005) who showed that meat from young sheep with partially erupted teeth is unlikely to be inferior in eating quality to meat currently classified as lamb.

In conclusion, processing sorghum grain by cracking or expanding did not significantly improve lamb performance in this experiment. While providing an additional $\mathrm{N}$ source significantly increased lamb performance on sorghum feedlot diets, there was no benefit in final carcass weight of lambs from substituting sources of true protein for non-protein N. This experiment has demonstrated that concentrates based on sorghum grain provide a basis for a finishing system for crossbred lambs for existing markets. Combined with economic parameters, these results provide options for feedlot diets under commercial conditions.

\section{Acknowledgements}

This study was funded by the Australian Sheep Industry Cooperative Research Centre with in-kind contributions from the Department of Primary Industries and Fisheries, Queensland (DPI\&F). We are grateful to the Health and Nutritional Biochemistry Laboratory of DPI\&F for conducting laboratory analyses.

\section{References}

Anon. (1975) 'Energy allowances and feeding systems for ruminants.' (Ministry of Agriculture, Fisheries and Food: London)

Anon. (2001) 'AUS-MEAT sheepmeat language.' (AUS-MEAT Ltd: Woolloongabba)

AOAC (1975) 'Official methods of analysis.' (Association of Official Analytical Chemists: Washington DC)

Bell AK, Shands CG, Hegarty RS (2003) 'Grain finishing of lambs.' (Meat and Livestock Australia: North Sydney)

Beretta V, Kirby RM (2004) Nutritional characteristics of cereal grains. In 'Feeding grain for sheep meat production'. (Ed. HM Chapman) pp. 33-39. (Chief Executive Officer of the Australian Sheep Industry CRC: Bentley)

Bird SH, Rowe JB, Choct M, Stachiw S, Tyler P, Thompson RD (1999) In vitro fermentation of grain and enzymatic digestion of cereal starch. Recent Advances in Animal Nutrition in Australia 12, 53-61.

Bolleter WT, Bushman CJ, Tidwell PW (1961) Spectrophotometric determination of ammonia as indophenol. Analytical Chemistry 33, 592. doi:10.1021/ac60172a034

Bowen MK, Ryan MP, Jordan DJ, Beretta V, Kirby RM, Stockman C, McIntyre BL, Rowe JB (2006) Improving sheep feedlot management. International Journal of Sheep and Wool Science 54, 27-34.

Bowen MK, Pepper PM, Patterson E, McConnel I, Jordan D (2007) Growth and carcass characteristics of cast-for-age Merino ewes fed sorghumbased feedlot diets. Australian Journal of Experimental Agriculture 47, 1309-1316.

Davis C (1977) Limits to production of sheep fed diets based on cereal grains. Australian Meat Research Committee Final Report DAN11S. AMRC and NSW Department of Agriculture, NSW.

Department of Primary Industries and Fisheries (2006) DPI\&F Note: livestock nutrition, supplementary feeding of sheep using cottonseed. Available at http://www2.dpi.qld.gov.au/sheep/8091.html [Verified 4 August 2007] 
Foss Tecator (2002a) Application sub-note ASN 3805. The determination of neutral detergent fibre using the Fibercap system. Foss Tecator, Hoganas, Sweden.

Foss Tecator (2002b) Application sub-note ASN 3804. The determination of acid detergent fibre using the Fibercap system. Foss Tecator, Hoganas, Sweden.

Foss Tecator (2002c) Application sub-note ASN 3801. The determination of crude fibre in feed according to AOAC, ISO, AACC and AOCS standards using the Fibercap system. Foss Tecator, Hoganas, Sweden.

Genstat Committee (2005) 'The guide to Genstat Part 2: statistics.' (VSN International Ltd: Oxford)

Hadjipanayiotou M, Georghiades E (1985) Digestibility of triticale and barley grains given to sheep whole, ground or treated with urea. Technical Bulletin 74, Agricultural Research Institute, Nicosia. pp. 1-5.

Huntington GB (1997) Starch utilization by ruminants: from basics to the bunk. Journal of Animal Science 75, 852-867.

Jones FM, Hegarty RS, Davis JJ (2004) Nutritional requirements of growing lambs: protein and energy requirements. In 'Feeding grain for sheep meat production'. (Ed. HM Chapman) pp. 13-23. (Chief Executive Officer of the Australian Sheep Industry CRC: Bentley)

Kent-Jones DW, Amos AJ (1957) 'Modern cereal chemistry.' 5th edn. (Northern Publishing Co. Ltd: Liverpool)

Malik RC, Razzaque MA, Abbas S, Al-Khozam N, Sahni S (1996) Feedlot growth and efficiency of three-way cross lambs as affected by genotype, age and diet. Proceedings of the Australian Society of Animal Production 21, 251-254.

McCleary BV, Gibson TS, Solah V (1992) A rapid procedure for total starch measurement in cereal grains and products. In 'Proceedings of the 42nd RACI cereal chemistry conference. Christchurch, New Zealand, 7-11 September, 1992'. pp. 304-312.

McIntyre BL, Ryan MP (2005) Effect of three different grain feeding systems on growth and carcass characteristics of crossbred and Merino lambs. Final Experiment Report, Sheep CRC Project 1.5.1: Simple and profitable grain feeding systems for lamb. Department of Agriculture, Western Australia and Australian Sheep Industry CRC, Perth.

McLennan SR (1997) Developing profitable strategies for increasing growth rates of cattle grazing tropical pastures. Project DAQ.100 Final Report. Queensland Department of Primary Industries, The University of Queensland and Meat Research Corporation, Moorooka.

Meat and Livestock Australia (2005) 'The lamb guide: a guide to Australian lamb production and marketing.' (Meat and Livestock Australia Limited: North Sydney)

Neutze S (1991) Degradation of feed protein in the rumen: degradability of common feeds and factors affecting degradation. NSW Agriculture Advisory Bulletin, Agdex 400/54.

Ørskov ER (1979) Recent information on processing of grain for ruminants. Livestock Production Science 6, 335-347. doi:10.1016/0301-6226(79) 90002-2
Ørskov ER, Smart R, Mehrez AZ (1974) A method of including urea in whole grains. Journal of Agricultural Science, Cambridge 83, 299-302.

Rooney LW, Pflugfelder RL (1986) Factors affecting starch digestibility with special emphasis on sorghum and corn. Journal of Animal Science 63, 1607-1623.

Rowe JB, Choct M, Pethick DW (1999) Processing cereal grains for animal feeding. Australian Journal of Agricultural Research 50, 721-736. doi:10.1071/AR98163

Ryan MP, McIntyre BL (2006) Effect of different systems of introducing lambs to grain feeding on subsequent production characteristics. Final Experiment Report, Sheep CRC Project 1.5.1: Simple and profitable grain feeding systems for lamb. Department of Agriculture, Western Australia and Australian Sheep Industry CRC, Esperance.

Searle TW, Graham NMcC (1970) Body composition of growing sheep and its relevance to pasture evaluation. Proceedings of the Australian Society of Animal Production 8, 472-475.

Searle TW, Graham NMcC (1972) Growth in sheep. I. The chemical composition of the body. Journal of Agricultural Science, Cambridge 79, 371-382.

Sweeney RA (1989) Generic combustion method for determination of crude protein in feeds. Journal of the Association of Official Analytical Chemists 72, 770-774.

Taylor J (1973) The analysis of designed experiments with censored observations. Biometrics 29, 35-43. doi:10.2307/2529674

Theurer CB, Huber JT, Delgado-Elorduy A, Wanderley R (1999) Invited review: summary of steam-flaking corn or sorghum grain for lactating dairy cows. Journal of Dairy Science 82, 1950-1959.

Van Soest PJ (1963) Use of detergents in the analysis of fibrous feeds. II. A rapid method for the determination of fibre and lignin. Journal of the Association of Official Agricultural Chemists 46, 825-829.

Van Soest PJ, Wine RH (1967) Use of detergents in the analysis of fibrous feeds. IV. Determination of plant cell-wall constituents. Journal of the Association of Official Agricultural Chemists 50, 50-55.

Wiese SC, White CL, Masters DG, Milton JTB, Davidson RH (2003) Growth and carcass characteristics of prime lambs fed diets containing urea, lupins or canola meal as a crude protein source. Australian Journal of Experimental Agriculture 43, 1193-1197. doi:10.1071/EA02134

Wiese SC, Pethick DW, Milton JTB, Davidson RH, McIntyre BL, Souza DND (2005) Effect of teeth eruption on growth performance and meat quality of sheep. Australian Journal of Experimental Agriculture 45, 509-515. doi:10.1071/EA03258

Ziggers D (2003) Expanding and structurizing. In 'Feed tech'. pp. 8-11.

Manuscript received 23 June 2006, accepted 2 May 2007 